\title{
Phase change materials (PCMs) integrated into transparent building elements: a review
}

\author{
Paris A. Fokaides ${ }^{1} \cdot$ Angeliki Kylili $^{1} \cdot$ Soteris A. Kalogirou $^{2}$
}

Received: 5 January 2015/Accepted: 23 March 2015/Published online: 2 April 2015

(c) The Author(s) 2015. This article is published with open access at Springerlink.com

\begin{abstract}
Phase change materials (PCMs) represent an innovative solution that can contribute to the improvement of the energy performance of buildings. Recently a trend towards integrating PCMs into transparent envelope components is observed. This study aims to present the main solutions proposed in the literature for applications in the past few years for PCMs integrated into transparent buildings elements. The temporal development of this application as well as the fundamental principles of its operation is described in detail. The concept of the existing transparent PCM systems is presented, and the rationale of selecting appropriate materials is discussed. This is followed by the current practices in testing the thermal performance of transparent PCMs. The future trends in terms of the current barriers and the potential improvements are discussed. To this end the future technologies of transparent PCMs are also considered.
\end{abstract}

Keywords Phase change materials (PCMs) - Transparent · Building elements

Paris A. Fokaides

eng.fp@frederick.ac.cy; p.fokaides@frederick.ac.cy

1 School of Engineering and Applied Sciences, Frederick University, Cyprus, 7., Y. Friderickou Str., 1036 Nicosia, Cyprus

2 Department of Mechanical Engineering and Materials Science and Engineering, Cyprus University of Technology, Limassol, Cyprus

\section{Introduction}

The promotion of buildings' energy efficient design is one of the main priorities of the research community in the building sector. A novel approach, which in recent years gaining more and more ground, is the use of phase change materials (PCMs). PCMs have the ability to change their phase (typically from solid to liquid and vice versa) at room temperature. This results to the storage of the amount of latent energy which is required to change the phase of the material. PCMs represent a highly efficient solution, as their use improves building shell's energy management. In particular, the use of these materials enables the better management of the energy flow to and from the building, decelerating in this way the rate of thermal losses. PCMs thermal performance is a challenging scientific field as the phase change is accompanied by a change of the materials' key properties, such as the heat capacity and thermal conductivity.

PCMs are used in a range of applications in the technical and building sector. In the latter case, they are mainly used in opaque components, typically in walls and ceilings. Lately, the use of PCM-doped infrared reflective coatings was reported [1]. However, in the recent years, a trend towards integrating these materials into transparent envelope components or employing transparent PCM in building systems is being observed. This review work focuses on the transparent glazing systems that incorporate PCMs, and considering the fact that these building components, particularly in warm dominant climates, are more vulnerable to thermal losses due to their higher thermal transmittance and higher radiation losses, this incorporation is of special importance.

The synthesis and the characteristics of stearic acid (SA)/expanded graphite (EG) composites as thermal

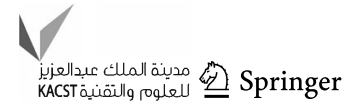


energy storage materials were reported in Fang et al. [2]. The authors denoted that the properties of these composites can be used in the exterior walls of buildings so that the cooling load of air-conditioning system is reduced. Similarly, the aim of the work of Chwieduk [3] was to point out ways of substituting thick and heavy thermal mass external walls, which are typical in buildings in high latitude countries, by thin and light thermal mass PCMincorporated walls that meet the same comfort levels throughout the whole year.

Additionally, Kuznik and Virgone [4] investigated experimentally the thermal performances of a PCM copolymer composite wallboard in a full-scale test room. The results indicated that the PCM-incorporated wallboard achieves the lowering of the air temperature in the room by up to $4.2{ }^{\circ} \mathrm{C}$ and also enhances the natural convection in the room. The authors also stated that the specific PCM is particularly interesting for its use in renovation building projects.

The work of Medina et al. [5] concerned with the merging of two building technologies, structural insulated panel and PCM, into a new product. The results of the thermal performance evaluation of their new product indicated that the peak heat flux reductions achieved with 10 and $20 \%$ PCM incorporation were 37 and $62 \%$ respectively, while the average reductions in daily heat transfer were 33 and $38 \%$ for concentrations of 10 and $20 \%$ PCM, respectively. The thermophysical properties and the process of melting of a PCM, an epoxy resin/paraffin spheres composite in particular, were investigated numerically and experimentally, using a transient hot plate apparatus and differential scanning calorimetry respectively [6]. Based on their findings the authors concluded that this material can be used to improve comfort, save energy in buildings and reduce the weight of wallboards. $\mathrm{Xu}$ and Li [7] developed a paraffin/diatomite/multi-wall carbon nanotubes composite PCM for its incorporation into thermal energy storage cement-based composites. The use of this kind of composite was found to have beneficial effects for improving the thermal conductivity and heat storage, without affecting the thermal properties, chemical compatibility and thermal stability of the cement-based composites.

Several reviews have been published on the use of PCM in buildings. Zalba et al. [8] presented the history of thermal energy storage with solid-liquid phase change. Materials used by researchers as potential PCM and commercial PCM were described, together with their thermophysical properties. Farid [9] published a review about PCM building applications, which provides an insight to efforts to develop new classes of PCMs for use in energy storage in building applications. Tyagi and Buddhi [10] published a comprehensive review of various possible methods for heating and cooling in buildings. The thermal performance of various types of systems like PCM Trombe wall, PCM wallboards, PCM shutters, PCM building blocks, air-based heating systems, floor heating, ceiling boards, etc., was presented. The main focus of Kenisarin and Mahkamov [11] review was the assessment of the thermal properties of various PCM, methods for heat transfer enhancement and design configurations of heat storage facilities to be used as a part of solar passive and active space heating systems, greenhouses and solar cooking.

Sharma et al. [12] review summarizes the investigation and analysis of the available thermal energy storage systems incorporating PCM for use in different applications. Zhu et al. [13] presented an overview of the previous research work on dynamic characteristics and energy performance of buildings due to the integration of PCM. Wang et al. [14] presented the concept of ideal energy-saving building envelope, which is used to guide the building envelope material selection and thermal performance design. Finally, a review on the use of PCM for the free cooling of buildings is presented by Aroul et al. [15].

This review paper aims to present the latest developments in the application of PCMs in transparent components. This is not considered in any of the above reviews. A brief history of the PCMs and the fundamentals of operation of PCMincorporated glazing systems will be primarily presented in sections "PCM-incorporated transparent glazing development and fundamentals of operation" and "Current practices of transparent PCM-incorporated systems", respectively. The main solutions that have been implemented in recent years and materials used in transparent phase change components as well as their main properties will be referred in section "Current practices in testing the thermal performance of transparent PCM-incorporated systems". A discussion regarding the current barriers, the considerations for their further development, as well as the near-future trends is presented in section "Future trends", while the findings of this review paper are given in the last section.

\section{PCM-incorporated transparent glazing development and fundamentals of operation}

\section{Transparent PCM and PCM-incorporated transparent glazing development}

The first documented use of a PCM as a form of latent heating was by Dr. Maria Telkes in 1948 [16]. The Hungarian research associate of Massachusetts Institute of Technology (MIT) became one of the pioneers in this field through the construction of the very first PCM heated house with architect Eleanor Raymond. The Solar One building housed approximately $4 \mathrm{~m}^{2}$ of Glauber salts, which were ventilated with fans to deliver warm air inside the building in winter, and cool air in summer. In fact, this 
system was able to keep the house warm for approximately 11 sunless days. After 3 years, the house failed because the utilized PCM lost most of its energy storage capacity [17]. Since then, the development of PCMs for passive heating has been widely studied [18, 19]; however, their application developments had been slow. Harland et al. [16] attributed this slow development to the high costs of PCMs that was an obstacle to become a design option.

The earliest mention in literature regarding translucent PCM was found in Manz et al. [20]. The authors of this study proposed a two-layered passive wall system, combining a salt hydrate phase change material and a transparent honeycomb-type insulation material (Fig. 1). The PCM was filled into glass containers, which were commercially available glass blocks. A few years later, Ismail and Henriquez [21] were the first to report on the results of an experimental investigation on simple and composite glass windows filled with PCM.

\section{PCM-incorporated transparent glazing fundamentals of operation}

The passive solar mechanism of PCM glazing systems is offered by the outer and inner insulating glazing units. The outer insulated glazing unit with suspended prismatic filter between the panes of glass reflects the higher angle sunlight back out, transmitting the low-angle sunlight into the inner unit that is filled with sealed polycarbonates into which the PCM is encapsulated. As a result, the strong sunlight of the summer is kept out of the building, while the lower angle winter sunlight is allowed to be captured by the PCM as shown in Fig. 2 [22]. A PCM material with a (low) melting point close to the comfort or operational temperature in the building and high latent heat of fusion has the great latent heat storage potential. This potential is enabled by the phase transition between the liquid and the solid state and thus allows an increase of the thermal inertia of the glazing system [23].

During the melting process from solar radiation, the specific heat of PCM increases to more than one hundred times to absorb a large quantity of energy [24]. By nighttime the external temperature decreases below the melting point of the PCM, so that the PCM starts to solidify, releasing into the building its stored energy. By the next morning, the PCM typically solidifies completely to start the cycle again [22]. The net effect of this process is the reduction of heat flow from outdoor to indoor space during daytime [24].
Fig. 1 Layout of TIM-PCM external wall system (Manz et al. [20])

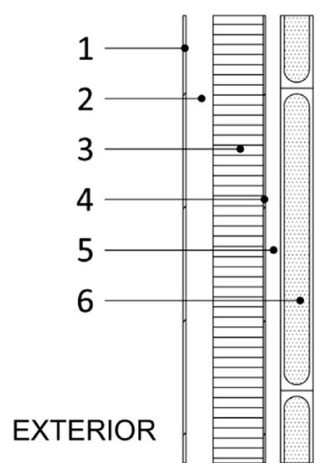

INTERIOR

\begin{tabular}{|c|c|c|}
\hline Layer Id & Description & $\begin{array}{c}\text { Thickness } \\
{[\mathbf{m m}]}\end{array}$ \\
\hline 1 & Glass pane & - \\
\hline 2 & Air gap & - \\
\hline 3 & $\begin{array}{c}\text { Transparent insulation } \\
\text { material }\end{array}$ & - \\
\hline 4 & Glass pane & - \\
\hline 5 & Air gap & - \\
\hline 6 & PCM in a glass container & \\
\hline
\end{tabular}

Fig. 2 Fundamentals of operation of transparent PCM (Figure reprinted with the written permission of the copyright holder)
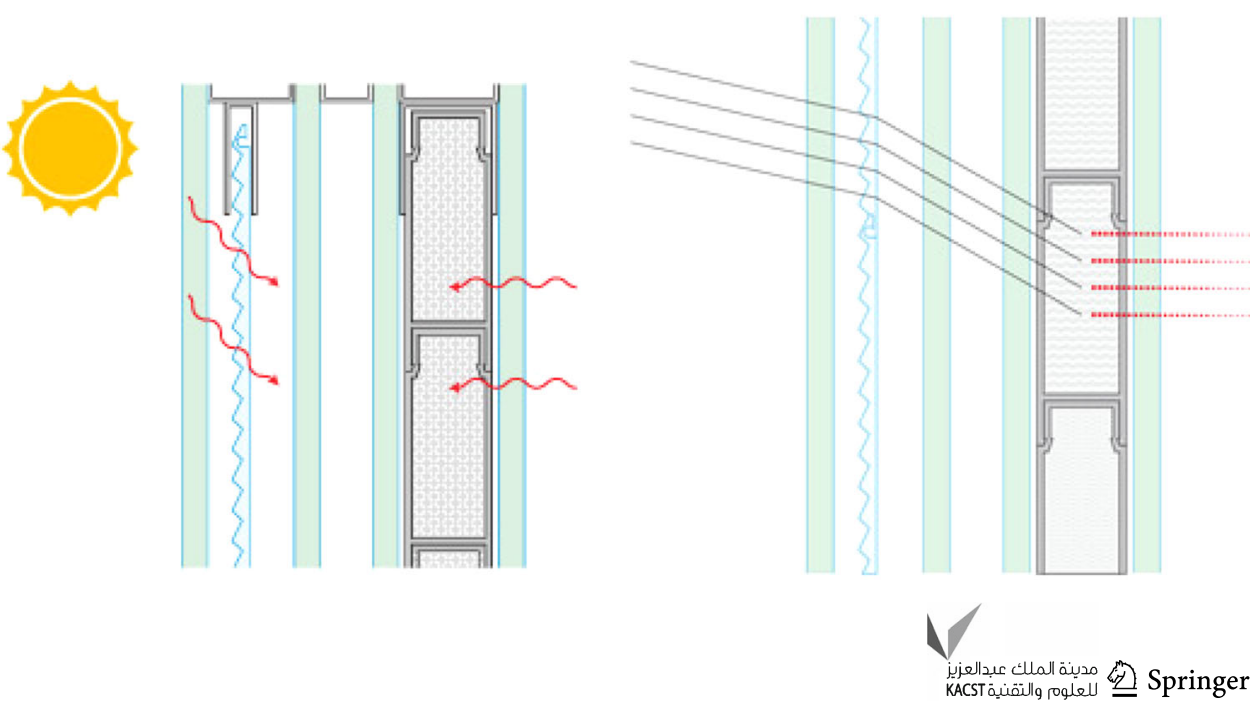


\section{Current practices of transparent PCM- incorporated systems}

\section{Concept of existing transparent PCM-incorporated wall systems}

Several transparent building elements incorporating translucent, or see-through, PCM have been proposed in the literature the recent years. Transparent PCM is a material that allows light to pass through but absorbs the infrared part of the spectrum and this increases the temperature of the PCM up to the point of melting, which as in all PCMs is done at constant temperature. The PCM can be transparent to the internal space, and act like a window, or it may be transparent to an opaque material (i.e., the wall element) in front of which it is installed. Ismail and Henriquez [21] presented a relatively simple and effective concept. The suggested layout consisted of a double glass window, separated by a gap of certain width, filled with a PCM of certain fusion temperature, as shown in Fig. 3.

Weinlaeder et al. [25] encapsulated PCMs in transparent plastic containers. The containers were placed behind a conventional double glazing with an air gap of about $10 \mathrm{~mm}$ as shown in Fig. 4. Numerical analysis of a double glazing containing PCM in the spacing between the two panes, shown in Fig. 5, was performed by Goia et al. [26]. A numerical procedure based on a $1 \mathrm{D}$ nodal model was
Fig. 3 Layout of double glass window with PCM (Ismail and Henriquez [21])

Fig. 4 Layout of PCM-facadepanel (Weinlaeder et al. [25])

Fig. 5 Layout of PCM glazing (Goia et al. [29])

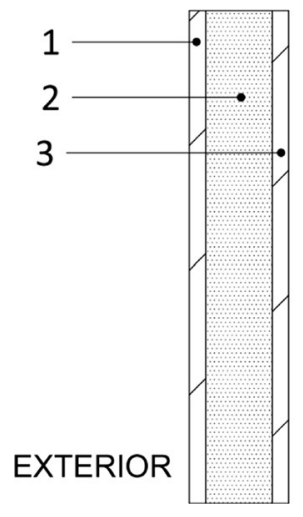

\begin{tabular}{|c|c|c|}
\hline Layer Id & Description & $\begin{array}{c}\text { Thickness } \\
{[\mathbf{m m}]}\end{array}$ \\
\hline 1 & Glass & - \\
\hline 2 & PCM Layer & - \\
\hline 3 & Glass & - \\
\hline
\end{tabular}

INTERIOR
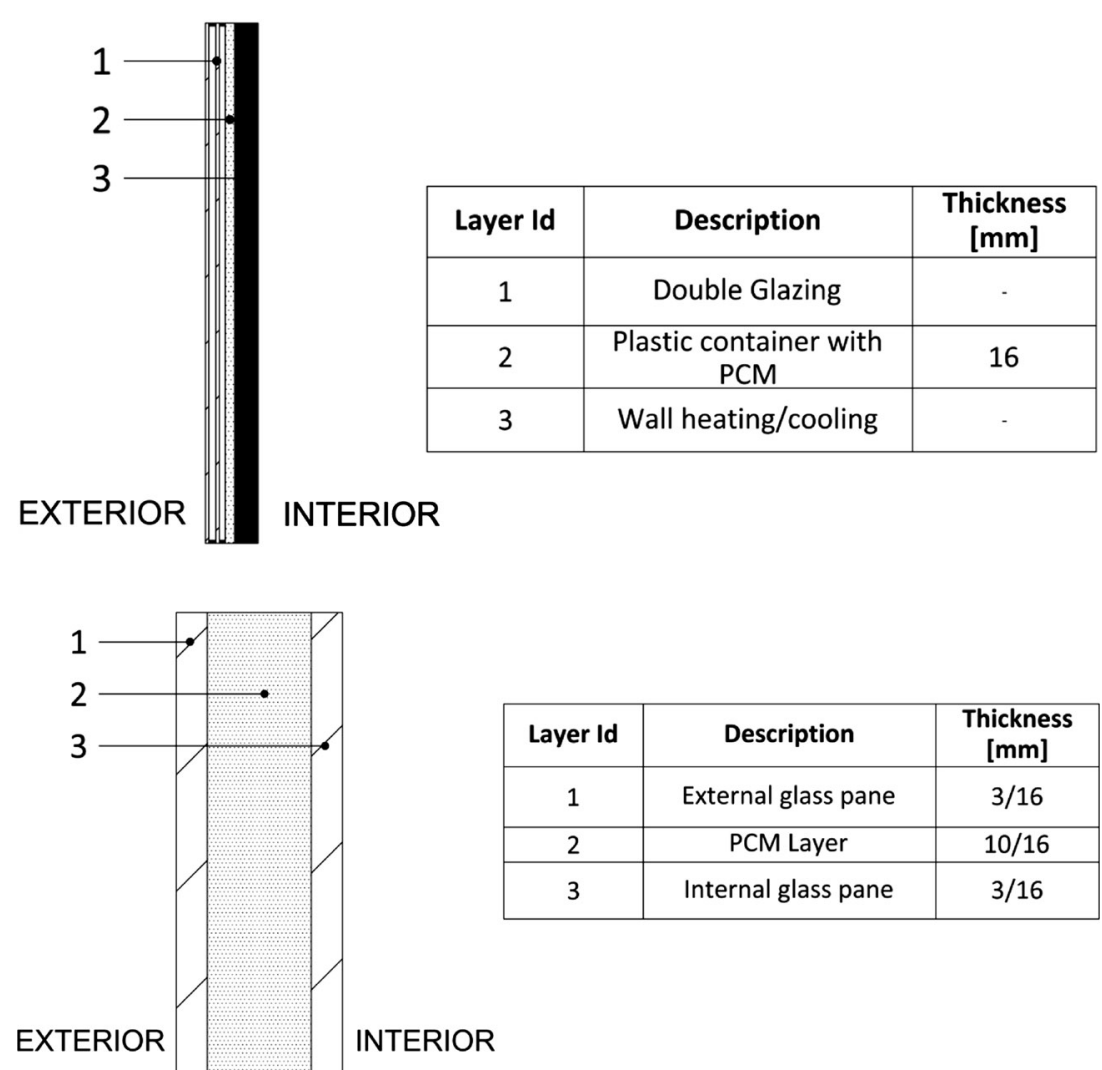
developed, neglecting heat and shortwave radiation transmission along the $x$ and $y$ axes. In their standard model, three nodes were associated to each glass pane, while the PCM layer was represented by means of five nodes.

In Goia et al. [27], a prototype of a simple PCM glazing system was proposed, while its behavior was compared with that of a conventional reference double glazed unit. The analysis indicated that the PCM glazing system provided better indoor thermal conditions than the conventional system for most of the time during the various seasons. In addition, it was found that the higher the outdoor solar irradiance, the greater the benefits offered by PCM glazing unit.

The aim of the study in Gowreesunker et al. [28] was the evaluation of the radiation heat transfer properties and performance of PCM glazing systems. The optical properties were evaluated using spectrophotometry and the thermal properties were assessed using the T-history method.

The aim of the work in Goia [29] was to investigate the location of the PCM layer and the nominal melting temperature of the PCM, which are two variables that play significant role in PCM glazing systems. Different PCM glazing configurations had been tested by means of a numerical analysis to assess their behavior with respect to the energy efficiency and thermal performance. The results indicated that the position of the PCM layer has a relevant influence on the thermophysical behavior of the PCM glazing system. PCM glazing systems, especially those with the PCM layer inside the outermost cavity can be beneficial in terms of thermal comfort, while a more complex evaluation is needed when the energy performance is addressed. The results of the work undertaken in Goia et al. [30, 31] have highlighted a good ability of the PCM glazing to store solar energy and to smooth and delay peak values of the total heat flux.

Buddhi et al. [32] investigated the thermal performance of a wooden box having a PCM-integrated window in south direction. The PCM employed was commercial grade lauric acid, which enabled to keep the temperature of the experimental test cell higher during evening and night. An experimental and numerical simulation study of the application of PCMs in translucent building elements was also presented in Bontemps et al. [33]. In fact, the experimental study was conducted in a test cell split by a wall made of hollow glass bricks filled with PCM. The PCMs tested were fatty acid, paraffin, and salt hydrate.

Additionally, a theoretical thermal analysis of a window with a shutter containing PCM was presented in Alawadhi [24]. The results indicate that the melting temperature of PCM must be close to the upper temperature limit of windows during daytime, while the quantity of PCM should be adequate to absorb a lot of heat during the day, without the PCM melting. Also, the presented shutter of $0.03 \mathrm{~m}$ thickness was able to reduce the heat gain by $23.29 \%$. The potential of incorporating PCMs in structural cells of shading elements associated to southward façade window was also presented in Soares et al. [34]. It was concluded that numerical simulation can be used to define an optimal system configuration, with an optimal PCM melting temperature for any location and characteristic climatic data.

Heim [35] carried out simulations of a transparent insulation wall integrated with a PCM. His system comprised of an external glazing, a transparent insulation material (TIM) honeycomb structure, and a PCM-ceramic composite, which were separated by air gaps to form a triple zone building model. The results showed the properties of the PCM enabled $5 \%$ more stable temperature for the internal space during winter. For the work of Weinlaeder et al. [36], an interior sun protection system consisting of vertical slats filled with PCM was monitored for more than 2 years. It was observed that the surface temperature on the interior side of the PCM-filled slats did not exceed the PCM melting temperature of $28{ }^{\circ} \mathrm{C}$, while conventional systems often reached $40{ }^{\circ} \mathrm{C}$. This proved the significant contribution of PCM technology in improving the thermal comfort of buildings.

Further to the incorporation of transparent PCM in transparent building elements, various PCMs have also been exploited as thermal storage materials for cooling, heating, thermal comfort, and thermal source in buildings [37]. Diarce et al. [38] investigated the thermal performance of a new type of ventilated active façade that includes a PCM in its outer layer, as shown in Fig. 6. Their prototype façade was designed to be suitable for use in building restoration. The external layer contains the PCM, inside an aluminum macroencapsulation system, and had a thickness of $20 \mathrm{~mm}$. The ventilated air channel was situated between the external layer and the insulation material, and it was $60 \mathrm{~mm}$ thick. Insulation material (50-mm-thick plates of extruded polystyrene) was placed next to the air gap. The inner layer was a brickwork wall made of 70-mm-thick hollow common bricks, and a 2-mm-thick plasterboard lined the inner walls of the room. A new type of ventilated facade with macro-encapsulated PCM in its air cavity, as shown in Fig. 7, was presented by De Gracia et al. [39]. The ventilated facade presented an air channel of $15 \mathrm{~cm}$ thick which represented $0.36 \mathrm{~m}^{2}$ of channel area. The inner layer was based on the alveolar brick constructive system while the outer envelope was made by a glass layer. An extra outer layer of expanded polyurethane panels was placed to cover the transparent glazing during the summer period since solar radiation inside the cavity was avoided for cooling purposes. 
Fig. 6 Layout of ventilated active façade (Diarce et al. [38])

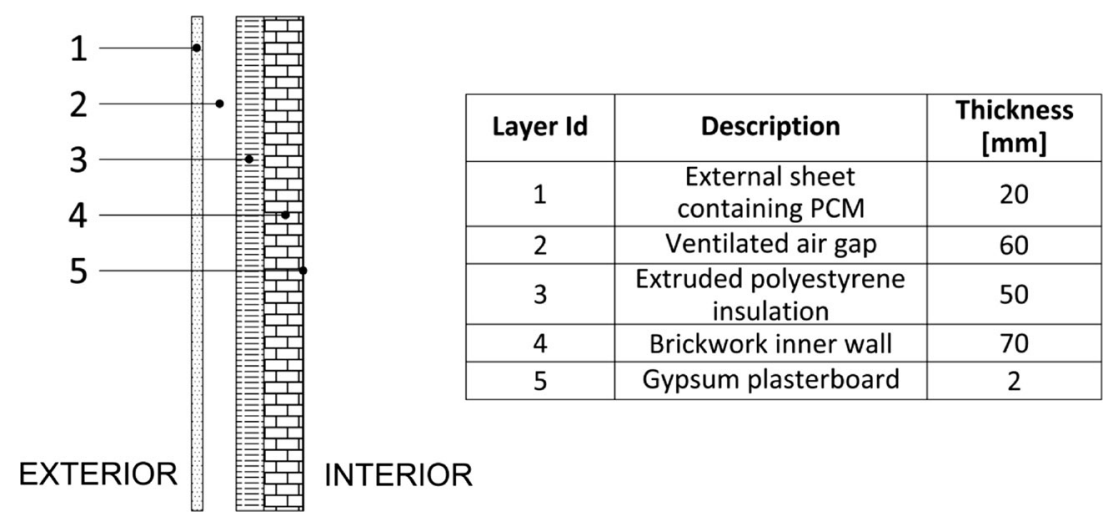

Fig. 7 Layout of ventilated facade with PCM (De Gracia et al. [39])

\begin{tabular}{|c|c|c|}
\hline Layer Id & Description & $\begin{array}{c}\text { Thickness } \\
{[\mathbf{m m}]}\end{array}$ \\
\hline 1 & Opaque insulation panel & - \\
\hline 2 & Glass layer & - \\
\hline 3 & $\begin{array}{c}\text { PCM panels and air } \\
\text { channel }\end{array}$ & - \\
\hline 4 & Alveolar brick & - \\
\hline
\end{tabular}

INTERIOR

\section{PCM materials used in transparent building elements}

More than $50 \%$ of incident solar radiation's energy is measured in the visible spectrum range. Based on this fact, the concept of a transparent element should allow visible radiation to be transmitted and invisible radiation in the infrared part of the spectrum to be absorbed and converted into heat. Therefore, the selected PCMs should not only have high heat capacity, but also favorable absorption and transmission under specific wave lengths. The light transmittance of water coincides perfectly with the sensitivity curve of the human eye. For this reason, high water content PCMs are mainly selected for transparent building elements. Subsequently, the same authors [20] used a salt hydrate PCM.

The categorization of PCMs as originally suggested by Abhat [40] is given in Fig. 8, and the main physical properties of the employed PCMs for transparent building elements are summarized in Table 1 . The use of $\mathrm{CaCl}_{2}$ $6 \mathrm{H}_{2} \mathrm{O}$ as PCM was first proposed by Swanton [41]. Manz [42] gives an overview of the research work which has been carried out to improve the thermal properties of the pure substance with additives, especially in order to suppress supercooling and to reach long-term stability. Their

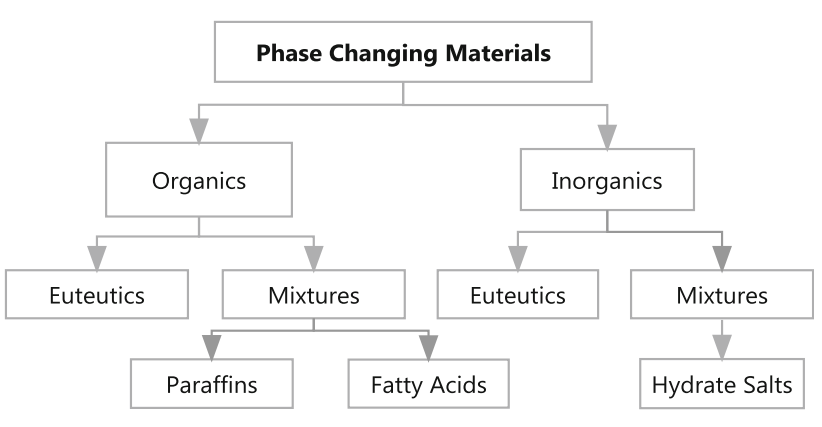

Fig. 8 Classification of PCMs (Zalba et al. [8])

experimental investigations were carried out using a commercially available PCM based on $\mathrm{CaCl}_{2} \cdot 6 \mathrm{H}_{2} \mathrm{O}$ with additives of approximately $5 \%$ of the mass. This material shows a melting enthalpy of $192 \mathrm{~J} \mathrm{~g}^{-1}$ and a melting temperature interval of $24-29{ }^{\circ} \mathrm{C}$. Porisini [43] tested the long-term stability of this PCM in small quantities and found no change in thermal properties after 5650 melting/solidification cycles. Later, Buddhi and Sharma [44] presented the experimental measurements of the transmissivity of commercial grade stearic acid, which revealed that the low thermal conductivity and high transmissivity of the material enabled its employment as a transparent insulating material. 


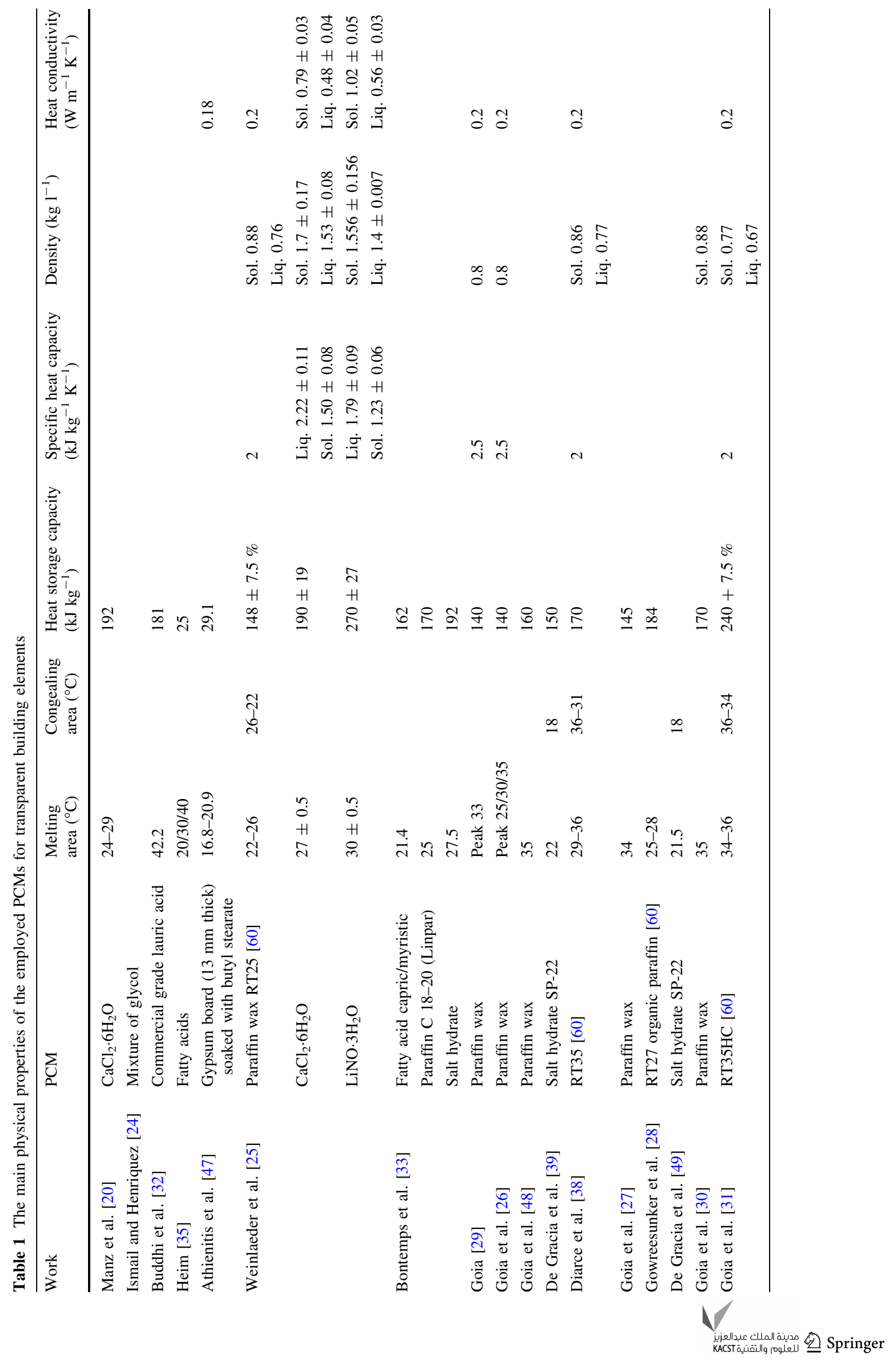




\section{PCM incorporated in glazing products}

Currently, there are commercially available types of glazing such as Delta ${ }^{\circledR}-$ Cool 28 or Glass $X^{\circledR}$ that incorporate $\mathrm{PCM}$. The PCM incorporated in the GlassX products is comprised of $\mathrm{CaCl}_{2} \cdot 6 \mathrm{H}_{2} \mathrm{O}$ salt hydrates that are completely sealed in clear polycarbonate. The products have a latent thermal storage of up to $4268 \mathrm{~kJ} / \mathrm{m}^{2}$, meaning that a period of $8 \mathrm{~h}$ passes before heat is transmitted [45]. This property shifts the peak energy demand of the summer later at night and thus reduces the interior room temperatures by at least $5{ }^{\circ} \mathrm{C}$. While in winter, the solar gains are maximized by charging up the PCM during the day in order to release it back into the building throughout the night as it solidifies. The manufacturers of Glass $X^{\circledR}$ claim that their products reduce a building's heating and cooling loads by $30-50 \%$ with only $1 / 3$ coverage on a south-facing façade compared to opaque, insulating walls such as brick, wood, or metal panels [45]. Regarding Delta ${ }^{\circledR}-$ Cool 28, the manufacturers demonstrated its application in translucent Polymethyl Methacrylate (PMMA) panels in a glass facade system of a zero energy office building in Kempen, Switzerland. Every other window panel was equipped with PCM for reducing the solar heating of the interior [46].

\section{Current practices in testing the thermal performance of transparent PCM-incorporated systems}

Both laboratory and outdoor testing facilities as well as specialized equipment were employed for the definition of the thermal performance of the proposed transparent building elements incorporating translucent PCM. Manz et al. [20] tested the PCM optical properties indoors in a laboratory using a spectrophotometer and Abbe refractometer, while the experimental investigation of the TIM and transparent PCM prototype facade was conducted in outdoor test facilities consisted of a cooling/heating apparatus and heat flow sensors. Their laboratory equipment allowed them to define also the refraction index of the PCM, while their outdoor test facility employed enabled them to measure also liquid mass flow temperatures, the heat flux, and the solar irradiance.

Ismail and Henriquez [21] characterized optically the different glass sheets of different thicknesses and panels of double sheets of different spacings and fillings employing only one laboratory equipment-a spectrophotometer. Consequently, their measurements were limited to the determination of transmittance, reflectance, and absorbance of the PCM. Athienitis et al. [47] had developed an outdoor test facility with two configurations of the double facade with photovoltaic panels that incorporated a differential scanning calorimeter (DSC), which recorded the latent heat and the transition temperatures of the glazing system. Weinlaeder et al. [25] and Goia et al. [26] set up their experiments for the PCM-integrated glazing systems in outdoor test cells. Temperature, heat flux, and incoming and transmitted solar radiation measurements were taken in the work of Weinlaeder et al. [25], while the outside test cell of Goia et al. [26], equipped with thermocouples, heat flux meters, and pyranometers collected data regarding the indoor surface temperatures of the glazing, the outdoor solar irradiance, the indoor surface heat flux, and also the transmitted solar irradiance of the PCM glazing system. For a subsequent work, Goia et al. [48] employed the Characterization of Advanced Transparent Materials (CATRAM) facility for the investigation of the proposed PCM-incorporated transparent system consisting of a halogen lamp and three array spectrometers.

Bontemps et al. [33] also configured outdoor test cells for the testing of the wall made of glass bricks filled with PCMs. Their equipment included fluxmeters and thermocouple for the measurements of heat flux and indoor temperature. Additionally meteorological data were taken from a nearby meteorological station. De Gracia et al. [39] used house-like cubicles with thermocouples, a moisture/temperature transducer, an electrical network analyzer, a heat pump, an air flow velocity-temperature transmitter, a pressure transmitter, and heat flux sensors for the investigation of their ventilated facade with macro-encapsulated PCM. Additional equipment, including solar pyranometers and an anemometer, was used for the data collection of the outdoor weather conditions. Their testing facility and equipment allowed them to take a range of measurements to evaluate the performance of the ventilated facade with macro-encapsulated PCM, which are given in Table 2. The active ventilated facade with a PCM, suggested by Diarce et al. [38], was studied in a PASLINK test cell with temperature probes and also employed air velocity sensors and pyranometers. Thus, in their work Diarce et al. [38] presented data of the global vertical radiation, the outdoor temperatures, and the temperatures inside the PCM at the bottom and the top of the façade.

Furthermore Goia et al. [27, 30] employed the Testing Window INnovative System (TWINS) outdoor test cell facility equipped with heat flux sensors, thermocouples and pyranometers for measuring solar irradiance, while Goia et al. [27] also employed an infrared thermal camera for their measurements. In his research, Gowreesunker et al. [28] employed an environmental chamber with controlled air temperature along with thermistors, a spectrophotometer, a pyranometer, and a $150 \mathrm{~W}$ metal halide (iodide discharge) lamp to enable the comparison between a PCM-glazed unit and a traditional 


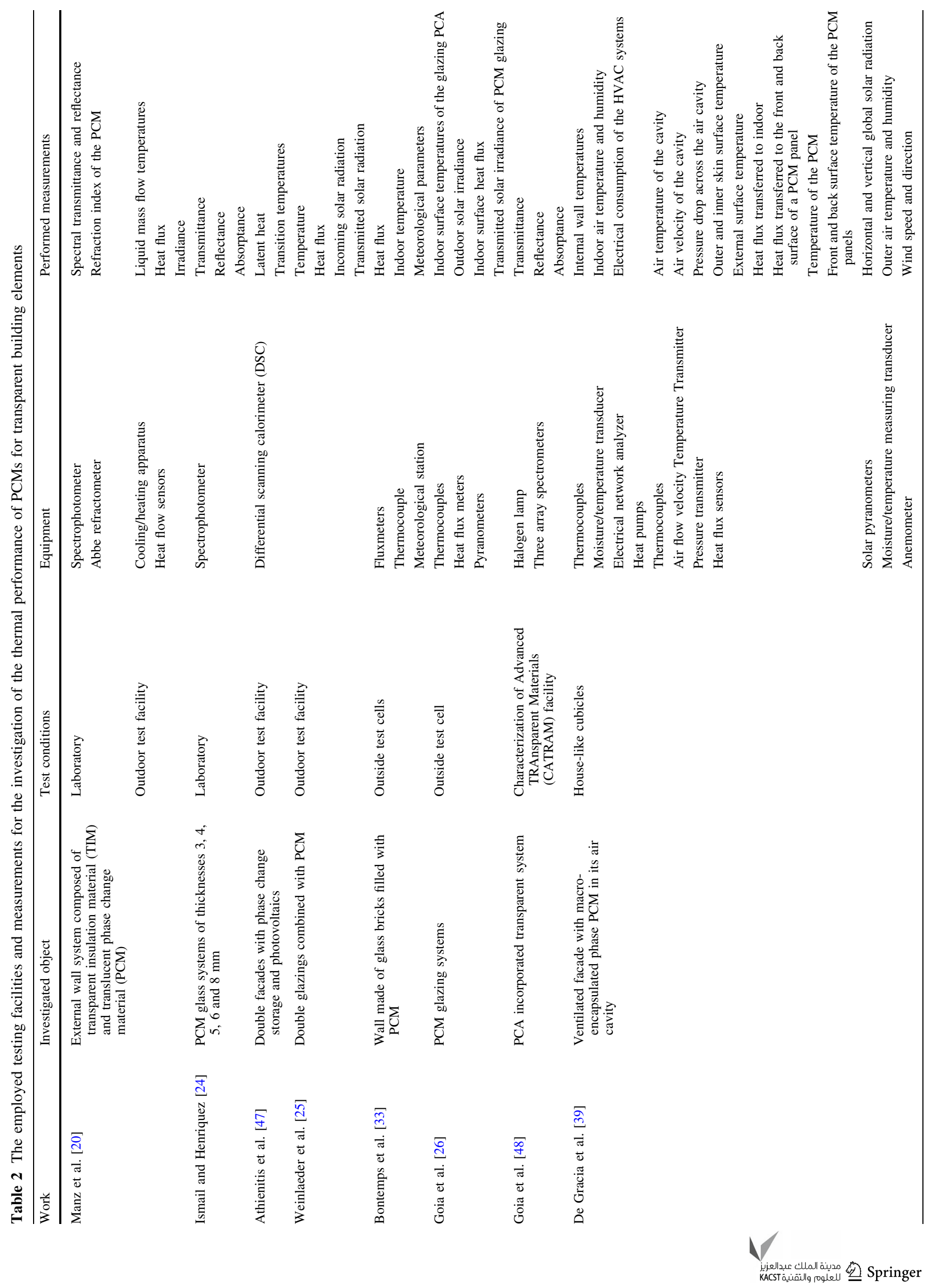




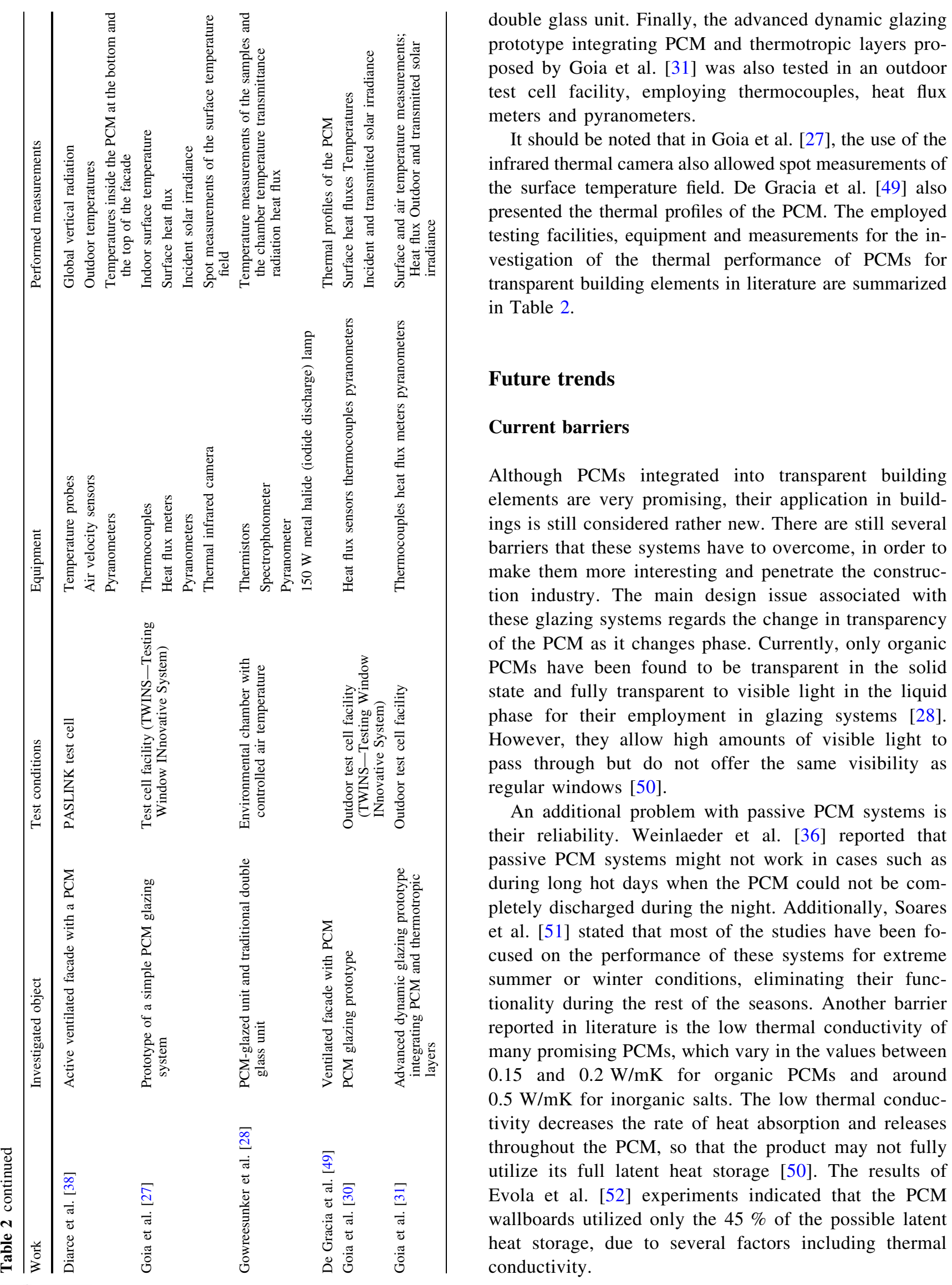




\section{Further work for improvements}

After the identification of the weak points of PCMs integrated into building elements, some areas of improvement are as follows:

- More accurate assessment of the performance and potential of PCM systems in real dynamic conditions is required [50, 53]

- Development of validated simulation tools for the modeling of PCM performance is required [53]

- Integration of the PCM solutions within the established buildings' thermal regulation codes through the development of methodologies that take into consideration the latent heat loads from the PCMs [50].

- Economic feasibility of PCM applications in the built environment needs to be carried out [53].

- Further research on the flammability of PCM; definition of the ratio of PCM fulfilling the building fire standards [53].

- Increasing the thermal storage capacity for a given volume of a PCM. Although microencapsulation reduces the risk of liquid state PCMs from leaking, it produces a lower latent heat storage capacity. Subsequently, new methods or materials need to be discovered for the encapsulation of the PCM, or thinner shell for the capsules need to be developed [50].

- Enhancing the heat transfer of the PCM [50]. Fan and Khodadadi [54] reviewed methods regarding this aspect, with porous materials with high thermal conductivity such as graphite-based PCM systems and metal foams receiving particular interest $[55,56]$. Also, materials with high thermal conductivity to the PCM, such as various carbon-based nano-fillers or porous structures have been studied for the enhancement of the overall thermal conductivity [57-59].

\section{Future technologies}

Building systems incorporating PCMs that harness solar thermal energy for heating during winter and optimized to reduce the overheating problem during summer are the most promising. Soares et al. [51] reported that the development of rotary, portable, movable and reconfigurable systems, mainly those associated with glazed façades, will be the next milestone in PCMs. Nanoencapsulation of PCMs, which has a similar concept to microencapsulation, and the combination of PCMs with nanofluids are also considered promising to improve PCM systems. Smaller size capsules would provide higher heat transfer speeds [50]. Another future trend of PCMs regards the adjustability of the phase change temperature for the improvement of the efficiency. A controllable or adaptive system would enable a dynamic change of the phase change temperature in response to user preferences, different climates and different seasons.

\section{Conclusions}

PCMs represent an innovative solution that can contribute to the improvement of the energy performance of buildings. A promising current trend concerns the integration of PCMs into transparent envelope components. This work introduces the evolution of PCMs technology for building applications, and thoroughly explains the concept of PCMs integrated into transparent buildings elements. The paper also reviewed the main solutions proposed by the literature in the past few years for PCMs integrated into transparent buildings elements. It can be concluded that PCM glazing systems provide better indoor thermal conditions than the conventional system, as they alleviated the peak heat temperatures of summer days, and release their stored energy during nighttime, when the outdoor temperatures typically drop. Finally, this work analyzes the barriers of the current PCMs technologies, and what can be done for their further development, as well as the near-future trends. In the next few years, rotary, portable, movable and reconfigurable glazing systems, nanoencapsulation of the PCMs, and systems with adjustable phase change temperature are anticipated to emerge.

Open Access This article is distributed under the terms of the Creative Commons Attribution 4.0 International License (http:// creativecommons.org/licenses/by/4.0/), which permits unrestricted use, distribution, and reproduction in any medium, provided you give appropriate credit to the original author(s) and the source, provide a link to the Creative Commons license, and indicate if changes were made.

\section{References}

1. Karlesi, T.M., Santamouris, M.: Research on thermochromic and PCM doped infrared reflective coatings. In: Kolokotsa, D., Santamouris, M., Akbari, H. (eds.) Advances in the Development of Cool Materials for the Built Environment, pp. 83-103. Bentham Publisher, Sharjah (2013)

2. Fang, G.H., Li, Z., Chen, X., Liu, X.: Preparation and characterization of stearic acid/expanded graphite composites as thermal energy storage materials'. Energy 35, 4622-4626 (2010)

3. Chwieduk, D.A.: Dynamics of external wall structures with a PCM (phase change materials) in high latitude countries. Energy 59, 301-313 (2013)

4. Kuznik, F.J., Virgone, J.: Experimental assessment of a phase change material for wall building use. Appl. Energy 86, 2038-2046 (2009)

5. Medina, M.A., King, J.B., Zhang, M.: On the heat transfer rate reduction of structural insulated panels (SIPs) outfitted with phase change materials (PCMs). Energy 33, 667-678 (2008)

6. Aadmi, M.M., Karkri, M., Hammouti, E.1.: Heat transfer characteristics of thermal energy storage of a composite phase change 
materials: numerical and experimental investigations. Energy, available online 10 June 2014

7. Xu, B., Li, Z.: Paraffin/diatomite/multi-wall carbon nanotubes composite phase change material tailor-made for thermal energy storage cement-based composites. Energy, available online 13 June 2014

8. Zalba, B., Marín, J.M., Cabeza, L.F., Mehling, H.: Review on thermal energy storage with phase change: materials, heat transfer analysis and applications. Appl. Therm. Eng. 23, 251-283 (2003)

9. Farid, M.M., Khudhair, A.M., Razack, S.A.K., Al-Hallaj, S.: A review on phase change energy storage: materials and applications. Energy Convers. Manag. 45, 1597-1615 (2004)

10. Tyagi, V.V., Buddhi, D.: PCM thermal storage in buildings: a state of art. Renew. Sustain. Energy Rev. 11, 1146-1166 (2007)

11. Kenisarin, M., Mahkamov, K.: Solar energy storage using phase change materials. Renew. Sustain. Energy Rev. 11, 1913-1965 (2007)

12. Sharma, A., Tyagi, V.V., Chen, C.R., Buddhi, D.: Review on thermal energy storage with phase change materials and applications. Renew. Sustain. Energy Rev. 13, 318-345 (2009)

13. Zhu, N., Ma, Z., Wang, S.: Dynamic characteristics and energy performance of buildings using phase change materials: a review. Energy Convers. Manag. 50, 3169-3181 (2009)

14. Wang, X., Zhang, Y., Xiao, W., Zeng, R., Zhang, Q., Di, H.: Review on thermal performance of phase change energy storage building envelope. Chin. Sci. Bull. 54, 920-928 (2009)

15. Aroul, A., Ra, V., Velraj, R.: Review on free cooling of buildings using phase change materials. Renew. Sustain. Energy Rev. 14, 2819-2829 (2010)

16. Harland, A., Mackay, C., Vale, B.: Phase change materials in architecture. In: Proceedings SB10 Wellington-innovation and transformation, held in May 2010, Wellington, New Zealand

17. Koekenbier, S.F.: PCM energy storage during defective thermal cycling design of the "Capacity Cube" and modelling of PCM pouches to trace the impact of incomplete thermal cycling. 2011. Delft University of Technology, Faculty of Mechanical, Maritime and Materials Engineering

18. Peippo, K., Kauranen, P., Lund, P.D.: A multicomponent PCM wall optimized for passive solar heating. Energy Build. 17, 259-270 (1991)

19. Peippo, K., Kauranen, P., Lund, P.D.: An organic PCM storage system with adjustable melting temperature. Sol. Energy 46, 275-278 (1991)

20. Manz, H., Egolf, P.W., Suter, P., Goetzberger, A.: TIM-PCM external wall system for solar space heating and daylighting. Sol. Energy 61, 369-379 (1997)

21. Ismail, K.A.R., Henriquez, J.R.: Parametric study on composite and PCM glass systems. Energy Convers. Manag. 43, 973-993 (2012)

22. GreenSpec. GreenSpec's website, high-tech glazing with phasechange material. http://greenspec.buildinggreen.com/ (2014)

23. Grynning, S., Goia, F., Rognvik, E., Time, B.: Possibilities for characterization of a PCM window system using large scale measurements. Int. J. Sustain. Built Environ. 2, 56-64 (2013)

24. Alawadhi, E.M.: Using phase change materials in window shutter to reduce the solar heat gain'. Energy Build. 47, 421-429 (2012)

25. Weinlaeder, H., Beck, A., Fricke, J.: PCM-facade-panel for daylighting and room heating. Sol. Energy 78, 177-186 (2005)

26. Goia, F., Perino, M., Haase, M.: A numerical model to evaluate the thermal behaviour of PCM glazing system configurations. Energy Build. 54, 141-153 (2012)

27. Goia, F., Perino, M., Serra, V.: Improving thermal comfort conditions by means of PCM glazing systems. Energy Build. 60, 442-452 (2013)
28. Gowreesunker, B.L., Stankovic, S.B., Tassou, S.A., Kyriacou, P.A.: Experimental and numerical investigations of the optical and thermal aspects of a PCM-glazed unit. Energy Build. 61, 239-249 (2013)

29. Goia, F.: Thermo-physical behaviour and energy performance assessment of PCM glazing system configurations: a numerical analysis'. Front. Archit. Res. 1, 341-347 (2012)

30. Goia, F., Perin, M., Serra, V.: Experimental analysis of the energy performance of a full-scale PCM glazing prototype. Sol. Energy 100, 217-233 (2014)

31. Goia, F., Bianco, L., Cascone, Y., Perin, M., Serra, V.: Experimental analysis of an advanced dynamic glazing prototype integrating PCM and thermotropic layers. Energy Proc. 48, 1272-1281 (2014)

32. Buddhi, D., Mishra, H.S., Sharma, A.: Thermal performance studies of a test cell having a PCM-window in south direction. In: IEA, ECESIA Annex 17, Advanced thermal energy storage through phase change materials and chemical reactions-feasibility studies and demonstration projects, 4th workshop, 21-24 March 2003, Indore, India, pp. 54-58

33. Bontemps, A., Ahmad, M., Johannès, K., Sallée, H.: Experimental and modelling study of twin cells with latent heat storage walls. Energy Build. 43, 2456-2461 (2011)

34. Soares, N., Samagaio, A., Vicente, R., Costa, J.: Numerical simulation of a PCM shutter for buildings space heating during the winter. World Renewable Energy Congress 2011, Sweden, 8-13 May

35. Heim, D.: Whole year analysis of TIM-PCM solar thermal storage wall. In: Proceeding of SimBuild 2004, IBPSA-USA National Conference Boulder, CO

36. Weinlaeder, H., Koerner, W., Heidenfelde, M.: Monitoring results of an interior sun protection system with integrated latent heat storage. Energy Build. 43, 2468-2475 (2011)

37. Deng, S., Wang, R.Z., Dai, Y.J.: How to evaluate performance of net zero energy building - a literature research. Energy, available online 2 June 2014

38. Diarce, G., Urresti, A., García-Romero, A., Delgado, A., Erkoreka, A., Escudero, C., Campos-Celador, A.: Ventilated active façades with PCM. Appl. Energy 109, 530-537 (2013)

39. De Gracia, A., Navarro, L., Castell, A., Ruiz-Pardo, A., Álvarez, S., Cabeza, L.F.: Thermal analysis of a ventilated facade with PCM for cooling applications'. Energy Build. 65, 508-515 (2013)

40. Abhat, A.: Low temperature latent heat thermal energy storage: heat storage materials. Sol. Energy 30, 313-332 (1983)

41. Swanton, J.R.: U.S. Patent 2'544'474 (1951)

42. Manz, H.: Sonnenstrahlungsbeladene Latent Wärmespeicher in Gebäudefassaden 1996. PhD thesis, Swiss Federal Institute of Technology, Zurich, Switzerland

43. Porisini, F.C.: Salt hydrates used for latent heat storage: corrosion of metals and reliability of thermal performance. Sol. Energy 41, 193-197 (1988)

44. Buddhi, D., Sharma, S.D.: Measurements of transmittance of solar radiation through stearic acid: a latent heat storage material. Energy Convers. Manag. 40, 1979-1984 (1999)

45. GlassX North America. GlassX's website, Home. http://www. glassxpcm.com/ (2014)

46. Delta ${ }^{\circledR}$. Delta ${ }^{\circledR}$, s website, Project Profiles. http://www.coselladorken.com/bvf-ca-en/projects/pcm/kempen.php (2014)

47. Athienitis, A.K., Zhang, J., Feldman, D.: A study of double facades with phase-change storage and photovoltaics'. International Conference "Passive and Low Energy Cooling for the Built Environment", May 2005, Santorini, Greece, pp. 855-859

48. Goia, F., Zinzi, M., Carnielo, E., Serra, V.: Characterization of the optical properties of a PCM glazing system. Energy Proc. 30, 428-437 (2012) 
49. De Gracia, A., Navarro, L., Castell, A., Cabeza, L.F.: Numerical study on the thermal performance of a ventilated facade with PCM'. Appl. Therm. Eng. 61, 372-380 (2013)

50. Kalnæs, S.E.: State-of-the-art and future building envelopes: application of low emissivity materials, phase change materials and vacuum insulation panels 2014. Master thesis, Norwegian University of Science and Technology

51. Soares, N., Costa, J.J., Gaspar, A.R., Santos, P.: Review of passive PCM latent heat thermal energy storage systems towards buildings' energy efficiency. Energy Build. 59, 82-103 (2013)

52. Evola, G., Marletta, L., Sicurella, F.: A methodology for investigating the effectiveness of PCM wallboards for summer thermal comfort in buildings'. Build. Environ. 59, 517-527 (2013)

53. Pomianowski, M., Heiselberg, P., Zhang, Y.: Review of thermal energy storage technologies based on PCM application in buildings. Energy Build. 67, 56-69 (2013)

54. Fan, L., Khodadadi, J.M.: Thermal conductivity enhancement of phase change materials for thermal energy storage: a review. Renew. Sustain. Energy Rev. 15, 24-46 (2011)
55. Sedeh, M.M., Khodadadi, J.M.: Thermal conductivity improvement of phase change materials/graphite foam composites. Carbon 60, 117-128 (2013)

56. Jiang, J., Zhu, Y., Ma, Y., Yang, D., Lu, F., Chen, J., Shi, J., Song, D.: Preparation and performance of bulk porous Al foams impregnated with phase-change-materials for thermal storage. Prog. Nat. Sci.: Mater. Int. 22, 440-444 (2012)

57. Babaei, H., Keblinski, P., Khodadadi, J.M.: Improvement in thermal conductivity of paraffin by adding high aspect-ratio carbon-based nano-fillers. Phys. Lett. A 377, 1358-1361 (2013)

58. Ji, P., Sun, H., Zhong, Y., Feng, W.: Improvement of the thermal conductivity of a phase change material by the functionalized carbon nanotubes. Chem. Eng. Sci. 81, 140-145 (2012)

59. Yu, S., Jeong, S.G., Chung, O., Kim, S.: Bio-based PCM/carbon nanomaterials composites with enhanced thermal conductivity. Sol. Energy Mater. Sol. Cells 120, 549-554 (2014)

60. Rubitherm. Rubiherm's website, RUBITHERM ${ }^{\circledR}$ PCM's. http:// www.rubitherm.de/english/ (2014) 